\title{
Inflation and Redistribution Processes in the Modern World
}

\author{
Tatiana Kotcofana ${ }^{1, *}$, Viktoria Bazzhina $^{1}$, and Armen Altunyan ${ }^{1}$ \\ ${ }^{1}$ University Saint-Petersburg State University, Faculty of Economics, 7-9, Universitetskaya nab., St. \\ Peterburg, 199034, Russian Federation
}

\begin{abstract}
.
Research background: Inflation and redistributive processes are the main permanent threats to economic stability in the modern world and these processes are closely interconnected. Inflation is a powerful tool for redistributing national income, both consciously used by economic entities and generated within the economic system.

Purpose of the article: To demonstrate the variety of mechanisms that connects inflation and redistributive processes in the modern economy.

Methods: The dialectical-materialistic and concrete-historical method forms the methodological basis of research. The empirical basis of analysis is formed by statistical materials and specific economic and statistical studies.

Findings \& Value added: Monopoly power in all its manifestations is the first and key mechanism for redistributing social income through inflation processes. The dollar's monopoly position in international settlements has long been one of the factors of global inflation processes and redistribution of the global public product in favor of the United States in the global economy. The highest degree of monopolization of Russian market is the main generator of Russian inflation and the reason of the disproportionate development of Russian economy. The state has the largest number of redistributive levers and quite often acts as a voluntary or involuntary initiator of inflation and redistribution processes. Inflationary expectations make a significant contribution to the formation of inflationary potential in the face of low confidence in the authorities, lack of information, political monopolism, and economic instability. This is manifested in advance overpricing for traded goods and services, interest rates, etc., which, in turn, may strengthen redistribution processes, especially in the context of monopolistic pricing.
\end{abstract}

Key words: inflation; redistribution of a social product; monopolies; public policy; inflation expectations

JEL Classification: $G 38$; $G 18$

*Corresponding author: t.kotsofana@spbu.ru 


\section{Introduction}

Problems of poverty, inequality, equitable distribution of income and wealth have invariably been among the issues widely discussed by the largest representatives of economics [1-3]. Indeed, redistributive processes are one of the most important permanent threats to economic stability in the modern world. They are aggravated by the global financialization inherent in the modern economy, which enslaves society and subordinates the entire economy to its logic. «For large banks and speculative funds, the satisfaction of private interests is increasingly at odds with the common good and interests of the economy» [4]. As a result, the financial sector no longer performs the function of optimal allocation of capital and risks and contributes to the further development of "casino finance". Due to these circumstances, the economy ceases to play its role and contribute to public welfare [5-6]. According to a study [7-9], income inequality caused by finance (financial development, financial liberalization and banking crises) is associated with greater redistribution of income than inequality caused by other factors.

These processes are closely intertwined with inflation, which is a powerful tool for the redistribution of national income, both deliberately used by economic agents and generated within the economic system. However the relationship between redistributive and inflationary processes, in our opinion, is two-sided, that is inflation is simultaneously a consequence of the desire of economic agents to redistribute the created social product and the reason for this redistribution, and the final results of redistribution processes do not always meet the interests of their initiators, which entails further attempts to redistribute the benefits using inflationary mechanisms. The article examines a variety of specific mechanisms of inflationary redistribution of benefits.

\section{Research methods}

The methodological basis of the research is the dialectical materialistic and concrete historical method. At the same time, the dialectical-materialistic approach is the initial principle of research. As applied to this study, this means that, on the one hand, the dialectical method allows to know the essence and causes of the processes considered in the most adequate reflection of their dynamic integrity, on the other hand, any theoretical research should be supported by historical practice and statistical data. In this regard the empirical basis of the analysis is statistical materials and specific economic and statistical studies.

\section{Results and Discussions}

\subsection{The redistributive nature of inflation}

Despite all the diversity of manifestations and ambiguity of the influence of inflationary processes on the economy, the main negative destructive property of inflation is the unevenness of price increases. Such unevenness is objective and inevitable; it also exists outside of inflation, but then it is less noticeable and not so effective. When inflation begins, the unevenness of price changes turns into a powerful destabilizing factor. It is inflation that impoverishes some and enriches others. After all, if all the value indicators simultaneously and evenly increased, nothing would change in society except the amount of money in circulation. But fully balanced inflation is a purely theoretical construct, but in reality it doesn't exist. 
Different changes in different types of prices mean real losses for individual economic entities. The main negative consequence of inflation is the tangible losses of significant segments of the population and entrepreneurs and, accordingly, the gain for their other part. Even the compensation (indexation) mechanism raises incomes following prices, which implies a loss for income owners. Whoever is the first to raise prices will be the winner, and whoever is the last to raise will be the loser, because he only compensates for his losses, and even then not completely. This feature of inflation contributes to its transformation into a self-reproducing process.

Thus, the peculiarity and at the same time the sore spot of inflation lies in the powerful redistributive potential, which it carries. In our view, when analyzing the causes of inflation, it is necessary to proceed precisely from its redistributive nature.

The nature of inflation, it seems to us, is rooted in a social conflict over the distribution of the social product between various social groups and strata of society. Some authors generally consider inflation primarily a social phenomenon, the nature of which lies outside the economic sphere [10-12]. In our opinion, despite the obvious intertwining of the social and economic aspects of the development of society, the roots of all social phenomena still lie in economic processes. And the issue of distribution and redistribution of social wealth, being social in its consequences, has an economic nature. However, in any case, the idea of the redistributive nature of inflation seems to us the most adequate for studying the genesis of inflationary processes in the modern economy.

The essence of this idea lies in the fact that inflationary processes arise and develop when all other forms of distribution and redistribution of the national product and national income have been exhausted, both between the stages of reproduction and sectors of the economy, and between social groups and strata of society as a whole. In this regard, the main source of inflation is the social conflict over the distribution of the social product. Such a conflict exists in any society, within any socio-economic system. However the condition for its implementation is the unequal opportunities of various economic agents, social groups and countries in access to the produced social product, due to the existing economic and institutional structures. As soon as at least one economic entity acquires economic power, which makes it possible to make an attempt to redistribute social wealth in its favor, this conflict transforms from a potential desire into real action, generating inflationary impulses.

The social conflict over the distribution of the social product finds its real embodiment in the structural disproportionality of the economy. The economic prerequisites for the violation of the value structure, as a direct cause of inflation, are, on the one hand, the uneven implementation of scientific and technical progress in production processes, and, consequently, unequal levels of productivity in different industries; on the other hand, there are differences in the impact of monopolistic forces on various sectors of the economy. Let's consider this mechanism in more detail.

Different industries in each separate period of time are subjects to varying degrees of technical restructuring under the influence of scientific and technological progress, therefore, at different times the prerequisites for improving the production process appear in them. Some industries generally do not lend themselves well to radical technical or organizational changes (for example, extractive industry, agriculture). This gives rise to unevenness and significant variability in the growth of sectoral labor productivity, causing the prerequisites for inflation in the field of economic relations are constantly emerging, gradually forming inflationary potential. The disproportionality of the economic structure is preserved thanks to the action of monopolies, which, while maintaining economic power in various industries, pursuing the goal of maintaining the profitability of production, objectively deepen the violations of value and price proportions in the entire system of reproduction relations. There is a law of price proportions, according to which the ratio 
between the values of the prices of all goods must correspond to the ratio of their values. This is a form of manifestation of the law of value in pricing. Any discrepancy in the proportions of prices compared with the proportions of the values of goods cannot be permanently maintained. The market as a spontaneous force brings the disturbed ratio to an objectively emerging value ratio. If the value of any product has changed, but the price remains the same, then the product will be sold at a price that does not correspond to the value. The commodity owner will either receive additional income at the expense of other commodity producers (in case the price is higher than the cost), or will be at a loss. But in conditions of free competition, this cannot continue indefinitely: due to intersectoral competition and capital overflow, price proportions will be restored in accordance with cost proportions [13]. The law of price proportions operates differently in the context of market monopolization. Modern chronic inflation is largely due to the emergence and spread of monopoly on pricing in all civilized countries. An inflationary rise of prices may be associated with holding prices at a stable level or even increasing them despite the decline in value. If the value of the goods of any enterprise decreases due to the growth of labor productivity, and the price for it does not change, then the price becomes higher than the value, which entails obtaining a monopoly superprofit equal to the difference between the monopoly high price (even if its absolute value has not changed) and the minimum price that would have developed in conditions of free competition (equal value). This monopoly super-profit is a deduction from the labor of the owners of other goods. Consequently, they sell their goods at a price that is lower than their value. The law of price proportions requires the restoration of the correct ratio of these values: if the prices of goods, the value of which has decreased, have not changed, the prices of other goods change, they will certainly rise. This increase will continue until the proportions between prices correspond to the proportions between the values of all commodities. And the higher the difference in the growth rates of labor productivity in different industries and enterprises, provided there is a monopoly on keeping the prices of goods, the cost of which has decreased, the longer the disproportions between the value and prices of goods accumulate, the more stable the growth in prices, the higher its rates. Inflation ends when the ratio of prices comes in line with the values of their values, and the incomes of normally operating enterprises in different industries become equal. But this will not happen soon, since the monopolies will strive to retain their previously achieved advantage over others in appropriating monopoly high profits. They, like others, will raise the prices of their goods, and they will have both formal grounds for this (the very fact of inflation in the country) and official justifications (an increase in the costs of purchased factors of production due to the general rise in prices) [14].

Redistribution is possible not only between manufacturers and industries, but also within large companies. An example is cross-subsidization of various types, in which, as you know, the costs of production of one type of goods or for one group of buyers are covered by a company at the expense of another type or group. As a result, on the one hand, production costs turn out to be underestimated, on the other - overestimated, due to the inclusion in them of a part of the costs of another type of goods or goods intended for sale to another buyer. In the Soviet period, cross-subsidization was one of the main forms of the redistribution of income from production both within enterprises and industries, and between industries, primarily between industry and agriculture. In the Western world, it is also no exception, it can even be assumed that its influence on the composition of production costs (in this sense) has a tendency to increase in modern conditions due to the widespread use of diversification of companies' activities as one of the conditions for ensuring their financial stability and strategic maneuvering on selected markets. A similar trend is also characteristic of Russian monopoly capital. 
Thus, the redistributive processes in modern society are closely related both to the monopoly power of individual economic entities and to the processes of inflationary price increases, and all these processes ultimately originate and find their embodiment in social conflicts over the primary distribution of the created social product and its subsequent redistribution.

\subsection{Inflationary mechanisms for the implementation of redistribution conflicts}

Social conflict over the distribution and redistribution of social income exists in any society, under any socio-economic conditions, and serves as a constant source of inflationary potential. In order to realize this potential, to turn inflation from a potential opportunity into reality, additional factors must be applied, and specific levers of redistribution must appear. And the difference in the definitions of inflation for national economies is expressed in the fact that the redistributive conflict as the underlying cause of inflation can be realized through a huge number of specific mechanisms. They are, as a rule, considered in the economic literature as specific causes and factors of the inflationary process. However, if we do not limit ourselves to stating the facts that lie on the surface of the observed phenomena, but investigate the deep processes that mutually influence each other, then we can come to the conclusion that all traditionally studied factors of inflation are based on the desire of economic agents to redistribute the income created in society. Let us show this using the example of individual inflationary mechanisms that are most relevant for the Russian economy.

As it has already been shown, one of the key causes of inflation in both the Russian and the world economy is monopoly on the country's domestic markets. A monopoly is precisely the economic entity that has sufficient market power to try to redistribute the social product in its favor. Henry Thornton, an eighteenth-century English economist, once wrote: "The question of price is a question of power and only power; if there is a shortage of any product, buyers find themselves more or less at the mercy of sellers, and the degree of this dependence is the greater, the more urgent the need for this product"[15]. In the world economy, the dollar's monopoly position in international settlements (although somewhat shaken in recent years) is one of the factors of global inflationary processes. The highest degree of monopolization of the Russian market, which is recognized by most economists, is, in our opinion, the main generator of Russian inflation. The proof of this position could be the subject of a separate article, here we will give only some data demonstrating the role of monopoly in unwinding the inflationary flywheel. Tables 1 and 2 show the relative growth rates of prices by industry and type of economic activity. They show that the rate of growth in prices in more monopolized industries is significantly ahead of the rate of growth in prices in industries where one can speak of at least relative competitiveness.

Table 1. Indices of relative prices for products of Russian industrial sectors in 2012 compared to 1990 , times.

\begin{tabular}{|c|c|}
\hline Industry & Index \\
\hline Industry average & 1.00 \\
\hline Fuel industry & 3.87 \\
\hline Ferrous metallurgy & 2.35 \\
\hline Non-ferrous metallurgy & 1.51 \\
\hline Power engineering & 1.48 \\
\hline Food industry & 0.94 \\
\hline Building materials & 0.69 \\
\hline Chemical & 0.68 \\
\hline Petrochemical & 0.66 \\
\hline
\end{tabular}




\begin{tabular}{|c|c|}
\hline Mechanical engineering & 0.57 \\
\hline Forestry, woodworking, pulp and paper & 0.43 \\
\hline Light industry & 0.28 \\
\hline
\end{tabular}

Source: [16]

Table 2. Indices of relative prices for the products of Russian industries in 2016 compared to 1998 and in 2018 compared to 2013, times.

\begin{tabular}{|c|c|c|}
\hline Industry & $\begin{array}{c}\text { Index } \\
\mathbf{2 0 1 6 / 1 9 9 8}\end{array}$ & Index 2018/2013 \\
\hline Industry in general & 1.00 & 1.00 \\
\hline Mining & 1.85 & 1.17 \\
\hline Manufacturing industries & 0.84 & 0.96 \\
\hline
\end{tabular}

Data source for calculation: website of the Federal State Statistics Service http://www.gks.ru

Unfortunately, Rosstat data in recent years do not allow analyzing price dynamics and, accordingly, calculating changes in relative prices for individual industries or types of economic activity, so that after 2012 the picture is quite blurry, but it is quite obvious that the extractive industries are characterized by a much less competitive environment rather than processing. Rosstat provides data only for goods sold within Russia, so the dynamics of world prices for raw materials in this case does not significantly affect the overall picture.

Besides, it is noteworthy that even after the events of the second half of 2008, when, due to understandable reasons of the external economic nature, prices for a number of energy commodities fell, they continued to grow in some other items: according to the results of this year, natural gas and steel pipes rose by 25 , and iron ore even $75 \%$ [17]. The latter fact is another indirect confirmation of the decisive influence of monopoly on price dynamics, since, according to the Federal Antimonopoly Service, the aggregate share of two economic entities (OJSC Metalloinvest, OJSC Severstal) operating on the iron ore pellet market within certain geographical boundaries is $100 \%{ }^{\dagger}$.

Another major cause of inflationary processes, traditionally called by economists, is the disproportionate development of the economy, deformation towards the backwardness of the consumer sector and the hypertrophied development of heavy industry. The Soviet economy was characterized by the excessive development of military engineering. In modern Russia, there are also structural imbalances, but this time in the direction of the raw materials industries and the financial intermediary sector to the detriment of the production of final goods and services (even ordinary consumer ones, not to mention high-tech ones). Table 3 shows the structure of gross value added by industry and type of economic activity in 2014-2018.

Table 3. The structure of gross value added by sectors of the economy (at current basic prices, as a percentage of the total).

\begin{tabular}{|c|c|c|c|c|c|}
\hline Industry & $\mathbf{2 0 1 4}$ & $\mathbf{2 0 1 5}$ & $\mathbf{2 0 1 6}$ & $\mathbf{2 0 1 7}$ & $\mathbf{2 0 1 8}$ \\
\hline Total & 100.00 & 100.00 & 100.00 & 100.00 & 100.00 \\
\hline $\begin{array}{c}\text { Agriculture, forestry, hunting, fishing } \\
\text { and fish farming }\end{array}$ & 3.90 & 4.30 & 4.27 & 3.90 & 3.60 \\
\hline Mining & 9.10 & 9.80 & 9.63 & 10.90 & 13.20 \\
\hline Manufacturing industries & 13.10 & 13.80 & 13.00 & 13.70 & 14.30 \\
\hline Provision of electricity, gas and & 2.70 & 2.80 & 2.93 & 2.90 & 2.70 \\
\hline
\end{tabular}

$\dagger$ Federal Antimonopoly Service of the Russian Federation. Report on the state of competition in the Russian Federation. URL: http://fas.gov.ru/about/list-of-reports/list-of-reports_30065.html (date accessed: 27.06.2012) 


\begin{tabular}{|c|c|c|c|c|c|}
\hline steam; air conditioning & & & & & \\
\hline $\begin{array}{c}\text { Water supply; wastewater disposal, } \\
\text { waste collection and disposal, } \\
\text { pollution elimination activities }\end{array}$ & 0.50 & 0.50 & 0.49 & 0.50 & 0.50 \\
\hline Building & 6.80 & 6.30 & 6.36 & 6.00 & 5.70 \\
\hline $\begin{array}{c}\text { Wholesale and retail trade; repair of } \\
\text { motor vehicles and motorcycles }\end{array}$ & 16.30 & 15.80 & 14.66 & 14.10 & 13.90 \\
\hline Transport and storage & 6.20 & 6.70 & 7.30 & 7.00 & 6.50 \\
\hline Hotel and catering activities & 0.90 & 0.90 & 0.91 & 0.90 & 0.90 \\
\hline $\begin{array}{c}\text { Information and communication } \\
\text { activities }\end{array}$ & 2.50 & 2.50 & 2.53 & 2.60 & 2.50 \\
\hline Financial and insurance activities & 4.50 & 3.60 & 4.41 & 4.40 & 4.30 \\
\hline $\begin{array}{c}\text { Real estate activities } \\
\text { Professional, scientific and technical } \\
\text { activities }\end{array}$ & 10.60 & 10.10 & 10.18 & 10.00 & 9.40 \\
\hline $\begin{array}{c}\text { Administrative activities and related } \\
\text { additional services }\end{array}$ & 2.00 & 2.40 & 2.42 & 2.40 & 2.30 \\
\hline $\begin{array}{c}\text { Public administration and military } \\
\text { security; social Security }\end{array}$ & 8.00 & 7.70 & 7.97 & 7.80 & 7.40 \\
\hline Education & 3.20 & 3.10 & 3.17 & 3.20 & 3.10 \\
\hline $\begin{array}{c}\text { Activities in the field of health and } \\
\text { social services }\end{array}$ & 3.40 & 3.20 & 3.18 & 3.10 & 3.30 \\
\hline $\begin{array}{c}\text { Activities in the field of culture, } \\
\text { sports, leisure and entertainment }\end{array}$ & 0.80 & 0.90 & 0.89 & 0.90 & 1.00 \\
\hline Provision of other types of services & 0.50 & 0.50 & 0.59 & 0.60 & 0.60 \\
\hline $\begin{array}{c}\text { Households as employers; } \\
\text { undifferentiated activities of private } \\
\text { households in the production of } \\
\text { goods and services for their own } \\
\text { consumption }\end{array}$ & 0.60 & 0.60 & 0.66 & 0.60 & 0.60 \\
\hline
\end{tabular}

Source: Federal State Statistics Service URL: https://rosstat.gov.ru/accounts

As you can see, in 2018, 13.2\% accounted for the extractive industries, $13.7 \%$ - for financial and insurance activities plus real estate transactions, $13.9 \%$ - for trade. Thus, in total, these activities account for $40.8 \%$ of all value added created in the economy. At the same time, the manufacturing industry (which includes, among other things, the primary processing of natural resources) provides $14.3 \%$ of gross value added. If we exclude the primary processing of minerals (the production of coke, oil products, metallurgical production), the share of the manufacturing industry will remain even less than ten percent. It turns out that almost half of the incomes received in the economy are not provided with real commodity content, which allows the inflationary flywheel launched by the monopolists to spin up without limiting prices from the effective demand side. The high level of monopolization of highly profitable industries further increases the disproportions in social reproduction, thereby securing exceptional opportunities for state-owned enterprises. Large monopoly enterprises are not interested in large-scale changes, increasing the efficiency of reproduction processes. To the greatest extent, this is confirmed by the behavior of enterprises in the energy industry: if it was necessary to modernize fixed assets, electricity tariffs were sharply increased in order to generate income to finance equipment renewal, to which the state responded by introducing strict price restrictions, in response to this, investments were immediately reduced over the year by $70 \%$, and the modernization processes came to naught. This is despite the fact that for many years the enterprises of this industry received super-profits, due to which investments should have been made. As shown above, these super-profits received by monopolists are not just huge additional earned, they are losses of other enterprises. It turns out that the capital seized 
from small firms that do not have monopoly power and special privileges, fully obeying the laws of the market, through inefficient distribution channels goes to the funds of the giants, and then simply dissolves, or rather, settles in the pockets of the owners of these enterprises in the form dividends ${ }^{\ddagger}$, while the entire economy, and industry in particular, is in dire need of capital ${ }^{\S}$. Such processes destabilize the state of the entire economy, exacerbate existing imbalances and promote the spread of these imbalances to other stages of reproduction.

Another factor of inflation, which has been increasingly mentioned by Russian economists in recent years, is the market power of intermediaries. Generally speaking, in a modern economy, the role of an intermediary is quite productive, since the complex structure of the economic system also presupposes a system of intensive distribution, when the consumer properties of a product include consideration of time, place, form and method of delivery. But this naturally leads to the fact that the share of the intermediary in costs grows $^{* *}$, which means that prices rise. In the Russian economy, intermediaries are a kind of "thrombus" in the process of economic exchange ${ }^{\dagger \dagger}$. This "thrombus" is especially sensitive in the agricultural market. At present, the share of all kinds of margins in the structure of the price of milk and bread reaches $60-80 \%$ and more (abroad it does not exceed $50 \%$, but most often it is $30-40 \%$ ) [21]. These imbalances are generated by a specific market phenomenon, which A.V. Golubev in his monograph [22] calls it a "pseudo-market mutant" - a home-grown speculator who has taken root thanks to the connivance of the authorities and sets the tone for the market space in Russia. The extremely high share of trade in the country's gross value added is an indirect confirmation of the huge role played by intermediaries ("resellers") in accelerating Russian inflation. No other type of economic activity has such a high share in GVA (13.9\% in $2018 \%)$. This is largely due to long chains of intermediaries, which are often artificially lined up. This artificiality is confirmed by the unnatural proportions of retail and wholesale trade. According to Rosstat, the total turnover of wholesale trade organizations in actual prices in 2018 was almost four times higher than the total turnover of retail trade organizations ${ }^{\S \S}$ (the ratio in terms of contribution to gross value added, respectively $8.2 \%$ - wholesale, $4.8 \%$ - retai $\left.{ }^{* * *} 1\right)$. According to the Rosstat methodology, wholesale trade includes any resale of goods to any professional users or other traders (wholesale or retail). Thus, it is obvious that such a high increase in value in Russian trade is due to the extremely high proportion of resellers. As a result, "after going through dozens of virtual links in the wholesale chain, ... the product arrives at the retail network hugely more expensive" [23]. Thus, in the sphere of trade, there is a redistribution of national income from producers and consumers to intermediaries.

The state quite often acts as a voluntary or involuntary initiator of inflationary processes, and the state has the greatest number of redistributive levers. This is a change in the size and structure of government spending, and manipulation of tax rates, and the

\footnotetext{
$\$$ Magalhães et al. in their study [18] showed that the greater the concentration, the more profits are distributed in the form of dividends, and the larger the share of income paid to capital

$\S$ Kaigorodova et al. showed in their study [19] that in Russia there is a tendency to an increase in the amount of money left outside the sphere of consumption or investment

${ }^{* *}$ According to some estimates, the producer's share in the final product price is only $20-25 \%$ (for comparison: in Soviet times - 60-65\%). That is, everything else, with the exception of wholesale and retail margins, is distributed among intermediaries (Rostov Regional Union of Consumer Societies // http://www.doncoop.ru/about/news/region/37).

i† A "thrombus" is understood to be an institutional structure in which the main increase in income is appropriated by intermediaries between the consumer and the producer, which as a result leads to inflation and a slowdown in economic growth [20].

$\$$ Federal State Statistics Service. URL: https://rosstat.gov.ru/accounts (date accessed: 09/05/2020)

$\S \S$ Federal State Statistics Service. URL: https://rosstat.gov.ru/bgd/regl/b19_58/Main.htm (date accessed: 09/05/2020)

${ }^{* * *}$ Federal State Statistics Service. URL: https://rosstat.gov.ru/accounts (date accessed: 09/05/2020)
} 
impact on the money supply, which is theoretically regulated by a formally independent Central Bank, but in Russian practice (and not only in Russia), as a rule, the actions of the Central Bank are a continuation of the Government's policy. The conscious policy of redistributing national income from one economic entity to another, pursued by the Russian state, is the most important mechanism that generates inflation in the Russian economy. In the $1990 \mathrm{~s}$, inflation, willingly or unwillingly, served as a tool for redistributing income from the population and enterprises to the financial sector of the economy and trade, which precisely due to this received the financial basis for their development. Nowadays with the help of inflationary processes, the national income is being redistributed in favor of natural monopolies and the raw materials sector, which is essentially also deeply monopolized. In many areas, the "instigators" of inflation are the branches of the quasi-public sector of the economy [23]. The annual rise in prices for gas, petrol, kerosene, diesel fuel, electricity and tariffs for transport services, prohibitively high lending rates of banks are the incentive for the revision and increase in prices. At the same time the price multiplier is starting to act. The final price of the consumed goods increases significantly due to the multiple growth of the primary increase of the price of an energy carrier or service. This growth, in its turn, occurs when goods move along the chain of cooperating producers, as well as as a result of the desire of each of them to maximize growth prices at their redistribution, because a formal reason for this has been received.

Even the monetarist concept, according to which inflation is always generated by an excess of means of payment in circulation, does not contradict the redistributive nature of inflation. In fact, this is just one of the channels of state influence on the distribution of national income. After all, money emission, including excessive, firstly, is generated by certain reasons, and not simply by the "evil will" of certain emission centers, and secondly, excessively issued means of payment are directed for certain purposes, or rather, at the disposal of certain economic entities, who benefit from this emission. Thus, the monetary theory of inflation is simply an analysis of a particular case of the unwinding of the inflationary process. And here we can agree with [24] that «Money is an endogenous variable that does not cause but just validates a going inflation».

Finally, another important factor in inflation is inflationary expectations. They stimulate an increase in the current demand to the detriment of savings and investment opportunities of the credit system, which makes them even more sustainable, as money turnover accelerates. Economic practice shows that if all members of society, especially active economic entities, expect inflation, then it arises. Moreover, an unpleasant feature of this factor is its self-reproducing nature - economic agents initiate the inflationary process by their actions, thereby confirming their expectations, which gives grounds to say that "inflationary expectations feed themselves". In the context of low confidence in the authorities, closed information, political monopoly and economic instability, inflationary expectations of Russian economic agents make a significant contribution to the formation of inflationary potential. Specifically, this is manifested, among other things, in the advance overstatement of prices for goods and services being sold ("pledging" future inflation into prices), interest rates, etc. But inflationary expectations in reality are almost never rational, that is, the expected (and priced) inflation rates rarely coincide with those that are actually observed. This, in turn, can intensify redistributive processes, especially in the context of monopoly pricing. An example is the tariffs for housing and communal services, which are annually indexed to the expected inflation rate, but in reality their growth significantly exceeds the growth rate of the consumer price index published by the official statistical bodies. Thus, by setting high inflation expectations in tariffs, utilities are actually reallocating funds in their favor due to the deviation of the expected inflation rate from the reality. [25-28] 


\section{Conclusion}

Summing up our reasoning, we can agree with those researchers who talk about inflation as a socio-economic phenomenon, which is largely generated by a person and to an even greater extent has a negative impact on his life [25]. Its negative consequences are in the redistribution of national income and national wealth, which is not associated with either economic efficiency or social justice. In an inflationary environment, benefits and costs are unevenly distributed among sectors of the economy, industries and enterprises. Therefore, inflation in the Russian and world economies has been and remains a tool for changing the proportions of the primary distribution of income between participants in the reproduction process and their subsequent redistribution.

The article was prepared with the financial support of the Russian Foundation for Basic Research (project 19-010-00751 \20).

\section{References}

1. Piketty, T., Yang, L., Zucman, G. (2019). Capital accumulation, private property, and rising inequality in China. American Economic Review, 109(7), 2469-2498.

2. Stiglitz, J. (2015). The origins of inequality, and policies to contain it. National Tax Journal, 68(2), 425-448.

3. Sen, A. (2015). The idea of justice: a response. Philosophy \& Social Criticism, 41(1), 77-88.

4. Rampini, A. A., Viswanathan, S. (2018). Financial intermediary capital. Review of Economic Studies, 85(4), 1937-1970.

5. Bernards, N. (2019). The poverty of fintech? Psychometrics, credit infrastructures, and the limits of financialization. Review of International Political Economy. May (Early Access).

6. Bresser-Pereira, L. C. (2019). Secular stagnation, low growth, and financial instability. International Journal of Political Economy, 48(1), 21-48.

7. Van Velthoven, A., De Haan, J., Sturm, JE. (2019). Finance, income inequality and income redistribution. Applied Economics Letters, 26(14), 1202-1209.

8. Kliestik, T., Michalkova, L., Kovacova, M. (2018), Is a tax shiled really a function of net income, interest rate, debt and tax rate? Evidence from Slovak companies. Journal of International Studies, 11(4), 295-311.

9. Simionescu, M., Balcerzak, A. P., Bilan, Y., Kotaskova, A. (2018). The impacts of money on output in Czech republic and Romania. Journal of Business Economics and Management, 19(1), 20-41.

10. Protasov, A.Y. (2011). Inflyatsiya $\mathrm{v}$ ekonomike SSSR: priroda, tsiklicheskaya dinamika, uroki dlya sovremennoy Rossii. Vestnik SpbGU, 5(4), 116-129.

11. Kamenetskiy, I.A. (1998). Inflyatsiya v perekhodnoy ekonomike Rossii (1992-1996 gg.). $\mathrm{SPb}$.

12. Flexner, Kurt F. (1994). Fleksner Kurt F. (1994). Prosveshchennoye obshchestvo. Ekonomika s chelovecheskim litsom. Per. s angl. M.: Mezhdunar. otnosheniya.

13. Liferenko, Y.V. (1991). Dinamika tsen v usloviyakh monopolizma sovetskoy ekonomiki. Politiko-Ekonomicheskiye Problemy Radikal'noy Khozyaystvennoy Reformy. Sb. nauchnykh trudov, Tver', 79-80. 
14. Liferenko, Y. V. (1994) Monopoliya na tsenoobrazovaniye - prichina inflyatsii. Rynochnaya i Nerynochnaya Monopoliya. Sb. nauchnykh trudov, Tver', 39-40.

15. Anan'in, O. (2002). Makroekonomika genri torntona ili o chem znali ekonomisty yeshche 200 let tomu nazad. Voprosy Ekonomiki, 12, 114-128.

16. Kornev, A. K. (2014). Proizvodstvennyy potentsial Rossii: Povysheniye konkurentosposobnosti obrabatyvayushchey promyshlennosti. Problemy Prognozirovaniya, 5, 53-69.

17. Turin, A. (2009). Ob inflyatogennoy roli monopol'nogo davleniya na rynok so storony energo-syr'yevykh korporatsiy. Rossiyskiy Ekonomicheskiy Zhurnal, 9-10, 91-93.

18. Magalhães, M., Sequeira, T., Afonso, O. (2019). Industry concentration and wage inequality: a directed technical change approach. Open Economies Review, 30(3), 457 481.

19. Kaigorodova, G. N., Mustafina, A. A., Alyakina, D. P., Pyrkova, G. Kh., Abduzalimov, I. R. (2018). Peculiarities of forming the savings by the Russian population in modern conditions. Revista San Gregorio, 25, 21-27. Special Issue: SI.

20. Orekhovskiy, P. (2010). Neekvivalentnyy obmen i svoystva prostranstva v ekonomicheskoy teorii. Voprosy ekonomiki, 8, 90-111.

21. Nazarenko, V. Golubev, A. V. (2010). Krizis i sel'skoye khozyaystvo Rossii (retsenziya na monografiyu). Voprosy Ekonomiki, 3,147-149.

22. Golubev, A. V. (2009). Krizis i sel'skoye khozyaystvo Rossii. M.: Kolos.

23. Daskovskiy, V., Kiselev, V. (2011). O mere i formakh gosudarstvennogo uchastiya. Ekonomist, 8, 27-50.

24. Bresser-Pereira, L. C. (2020). Financing COVID-19, Inflation and the Fiscal Constraint. Forum For Social Economics. JUL (Early Access)

25. Khokhlov, B. V. (2008). Sotsial'naya sostavlyayushchaya inflyatsii. Trud i Sotsial'nyye Otnosheniya, 10, 29-32.

26. Hong, H., Sraer, D., Yu, J. (2017). Inflation bets on the long bond. Review of Financial Studies, 30(3), 900-947.

27. Comber, J.-L., Debrun, X., Minea, A. et al. (2018). Inflation targeting, fiscal rules and the policy mix: Cross-effects and interactions. Economic Journal, 128(615), 27552784.

28. Kovacova, M., Kliestik, T., Valaskova, K., Durana, P., Juhaszova, Z. (2019). Systematic review of variables applied in bankruptcy prediction models of Visegrad group countries. Oeconomia Copernicana, 10(4), 743-772. 